\title{
Contact System Activation and Cancer: New Insights in the Pathophysiology of Cancer- Associated Thrombosis
}

\author{
E. Campello ${ }^{1}$ \\ M.W. Henderson ${ }^{2}$
}

D.F. Noubouossie ${ }^{2}$

P. Simioni ${ }^{1}$

N.S. Key ${ }^{2}$

\begin{abstract}
Address for correspondence Nigel S. Key, MB, ChB, FRCP, Division of Hematology/Oncology, Department of Medicine, University of North Carolina at Chapel Hill, 1079 Genetic Medicine Building, CB \#7035, 120 Mason Farm Road, Chapel Hill, NC 27599, United States (e-mail: nigel_key@med.unc.edu).
\end{abstract}

\begin{abstract}
Keywords

- contact activation

- cancer

- hypercoagulability

- intrinsic pathway

- thrombosis

Cancer induces a systemic hypercoagulable state that elevates the baseline thrombotic risk of affected patients. This hypercoagulable state reflects a complex interplay between cancer cells and host cells and the coagulation system as part of the host response to cancer. Although the tissue factor (TF)/factor VIla pathway is proposed to be the principal initiator of fibrin formation in cancer patients, clinical studies have not shown a consistent relationship between circulating TF levels (often measured as plasma microvesicle-associated TF) and the risk of thrombosis. A renewed interest in the role of the contact pathway in thrombosis has evolved over the past decade, raising the question of its role in the pathogenesis of thrombotic complications in cancer. Recent observations have documented the presence of activation of the contact system in gastrointestinal, lung, breast and prostate cancers. Although the assays used to measure contact activation differ, and despite the absence of standardization of methodologies, it is clear that both the intrinsic and extrinsic pathways may be activated in cancer. This review will focus on recent findings concerning the role of activation of the contact system in cancer-associated hypercoagulability and thrombosis. An improved understanding of the pathophysiology of these mechanisms may lead to personalized antithrombotic protocols with improved efficacy and safety compared with currently available therapies.
\end{abstract}

\section{Introduction}

Patients with cancer are at increased risk to develop venous thromboembolism (VTE), an association that is commonly known as Trousseau's syndrome. ${ }^{1,2}$ The clinical manifestations of cancer-associated VTE include deep vein thrombosis and pulmonary embolism, as well as visceral or splanchnic vein thrombosis. ${ }^{3}$ Indeed, cancer is one of the best-established risk factors for VTE. ${ }^{4,5}$ It has been estimated that 20\% of all first VTE events are associated with cancer. ${ }^{5}$ According to a recent U.K. cohort study that included 6,592 cancerassociated VTEs, the incidence rate of first VTE in patients with active cancer was 5.8 (95\% confidence interval $[\mathrm{CI}]$, 5.7-6.0) per 100 person-years and the overall incidence rate for recurrence was 9.6 (95\% CI, 8.8-10.4) per 100 personyears. ${ }^{6}$ Finally, cancer-associated thrombosis is linked with a worse prognosis, and thromboembolism is the second leading cause of death in cancer. ${ }^{5}$

Several risk factors for VTE usually coexist in cancer patients. These may include certain comorbidities, surgery, 
immobility, tumour histology and stage, the presence of indwelling central venous catheters and chemotherapy and/or some molecular targeted therapies. ${ }^{6}$ These risk factors, which may be classified as patient-, tumour- or treatment-related, may additively exceed the threshold for clinically overt thrombosis (-Fig. 1).

Tissue factor (TF) is the physiologic activator of coagulation in vivo. We and others have reported elevated levels of TF in the circulation of animal models and in patients with cancer. ${ }^{7,8}$ However, although circulating levels of TF correlate with mortality, it does not always correlate with markers of systemic hypercoagulability, or the occurrence of thrombosis. ${ }^{9-11}$ This suggests that other pathways modulate thrombogenesis in cancer. This review will focus on the hypercoagulable state in cancer with particular reference to recent findings concerning the potential contribution of the contact system (CS) of coagulation.

\section{The Contact System}

\section{FXII-Dependent Contact Activation}

The CS refers to a proteolytic pathway consisting of the zymogens factor XII (FXII) and prekallikrein (PK), and the non-enzymatic cofactor, high molecular weight kininogen (HK). Some definitions also include zymogen FXI. All component proteins are synthesized and secreted by the

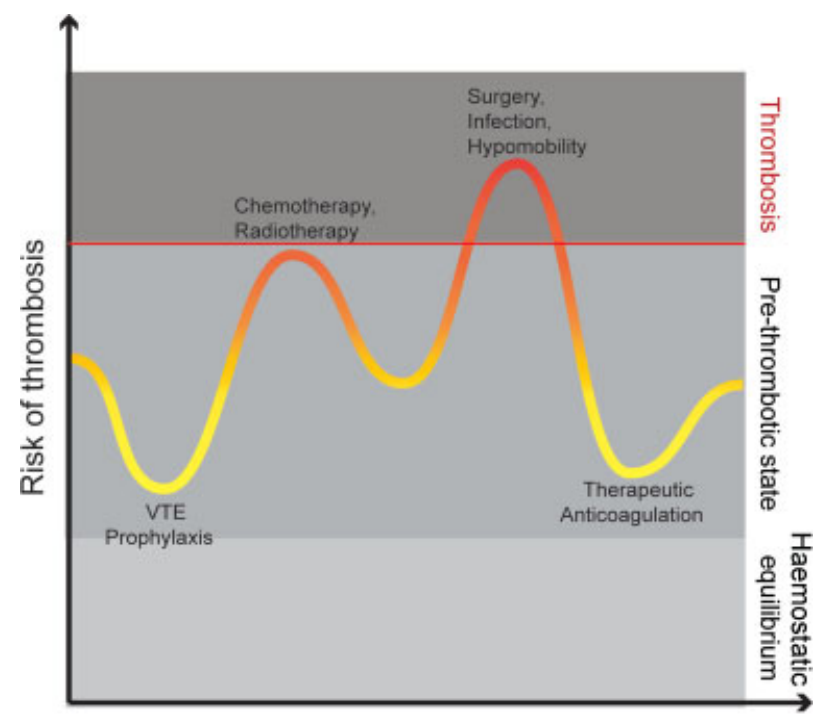

Time since cancer diagnosis

Fig. 1 Longitudinal risk of thrombosis in a patient with cancer. Normal individuals maintain a haemostatic equilibrium whereas cancer patients are typically in a pre-thrombotic state, and at risk of developing overt thrombosis. The coloured line represents the level of thrombotic risk in a cancer patient following diagnosis as (s)he progresses through various therapeutic interventions that may increase or decrease the basal thrombotic risk induced by the cancer. Thus, the patient may initially receive short-term thromboprophylaxis, which temporally lowers the risk of thrombosis. (S)he may then begin neoadjuvant radiation and/or chemotherapy, leading to an increased risk of thrombosis. When (s)he then undergoes surgery and is immobilized for several days, (s)he crosses the thrombotic threshold and develops a clinically overt thrombotic event. The risk of thrombotic recurrence remains high despite anticoagulation therapy. liver. ${ }^{12,13}$ Contact of plasma with negatively charged surfaces induces a conformational change in zymogen FXII resulting in a small amount of auto-activated FXII (FXIIa; $\alpha$-FXIIa), which, in turn, cleaves PK to generate kallikrein (KAL). The conformational change in FXII, together with reciprocal activation of FXII by formed KAL and HK, leads to further formation of FXIIa. ${ }^{12-15}$ The activation of FXII and PK generates a potent activation feedback loop that overcomes inactivation of these enzymes by the principal CS inhibitor, the serpin $\mathrm{C} 1$ esterase inhibitor (C1INH). ${ }^{16}$ The end result of FXIIa generation may be activated FXI (FXIa) and/or vasoactive and pro-inflammatory kinins, such as bradykinin (BK). FXIa initiates a series of $\mathrm{Ca}^{2+}$-dependent proteolytic events that lead to thrombin generation, and production of a fibrin clot. Following the initial generation of thrombin (by whatever mechanism), a powerful amplification mechanism accelerates thrombin formation in a FXI-dependent manner. ${ }^{16}$ Additionally, $\alpha$-FXIIa can be further cleaved by KAL to generate $\beta$-FXIIa, which retains the ability to activate PK, but not FXI or FXII, and is able to dissociate from the surface (contact phase). ${ }^{15,17,18}$ C1INH targets both FXIIa and KAL, accounting for $\sim 93 \%$ of plasma FXIla or $\beta$-FXIIa inhibition. Furthermore, antithrombin, $\alpha_{2}$-macroglobulin and $\alpha_{2}$-antiplasmin also inhibit FXIla to a lesser extent (-Fig. 2). ${ }^{19-24}$ Apart from glass surfaces, many other negatively charged surfaces or polyanionic molecules, including silica, kaolin, ellagic acid and sulphated polysaccharides, can accelerate contact activation. Certain glycosaminoglycans (GAGs), such as dermatan sulphate, chondroitin sulphate-E and heparin can also initiate contact activation in vitro ${ }^{18}$ or in vivo. ${ }^{25}$ However, over the past decade, intensive research efforts have focused on endogenous 'natural activators' of the CS. Several damage-associated molecular entities have been suggested to directly drive CS activation during vascular injury and infection including extracellular nucleic acids, misfolded aggregated proteins, mast cell heparin and pathogen-related molecules, such as endotoxin. Additionally, inorganic polyphosphate (polyP), a linear polymer of orthophosphates that is present in many infectious microorganisms and is also secreted by mast cells and platelets, has received the most attention. PolyP accelerates blood clotting and slows fibrinolysis, in a manner that is highly dependent on polymer length. Very long-chain polyP (found in many bacteria) is an especially potent trigger of the contact pathway, ${ }^{26-29}$ but aggregated shorter chain polyP in the form of $\mathrm{Ca}^{2+}$-dependent nanoparticles may also activate FXII. ${ }^{30}$ Recently, it was demonstrated that membrane-associated platelet polyphosphate condensed into insoluble spherical nanoparticles on the surface of activated platelets potently activates factor XII. ${ }^{31}$ Finally, extravascular matrix proteins such as laminin and collagen are capable of assembling and activating the CS to drive coagulation under flow conditions. $^{32}$

\section{The FXII-Independent Activation Pathway}

An alternate activation mechanism of the CS, independent of FXII, but involving $\mathrm{Zn}^{2+}$ - and HK-dependent PK activation on endothelial cells, has been described. It has been observed that 


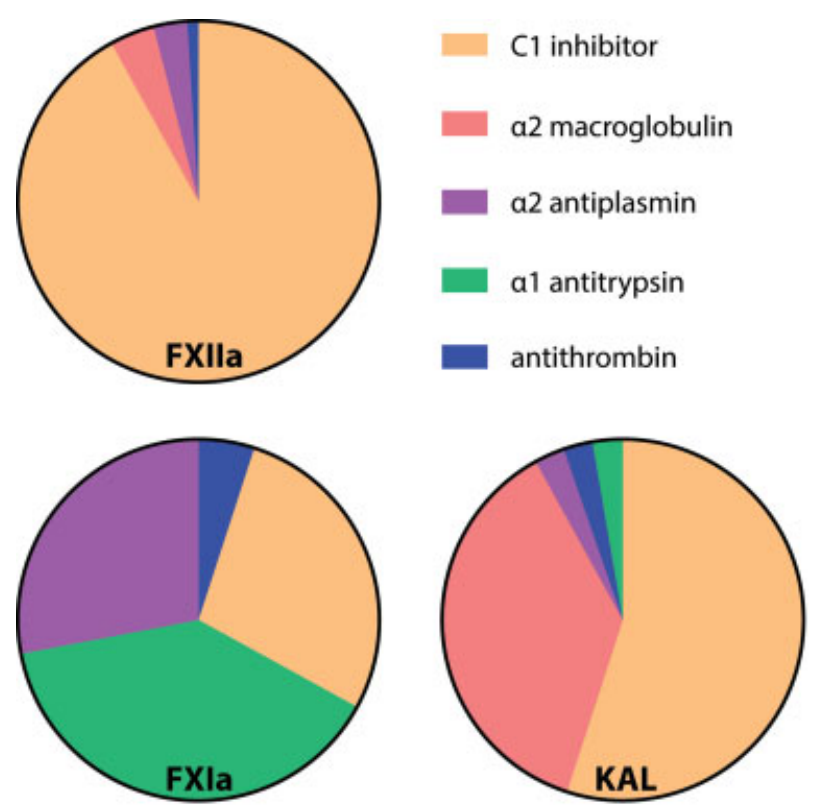

Fig. 2 Inhibitors of the contact system in plasma. The relative contributions of inhibitors of factors XIla (FXIla), Xla (FXla) and kallikrein (KAL) in plasma (in the absence of heparin) is illustrated. FXIla is predominantly complexed with $\mathrm{C} 1$ inhibitor, which typically accounts for $>90 \%$ of inhibition. ${ }^{20}$ FXla is inhibited by $\alpha 1$-antitrypsin ( 39\%), C1 inhibitor (28\%), $\alpha 2$-antiplasmin (28\%) and anti-thrombin (5\%). However, the addition of heparin greatly increases the contribution of antithrombin in FXla inactivation ( $235 \%$ of complexes).$^{21} \mathrm{C} 1$ inhibitor (55\%) and $\alpha 2$-macroglobulin (37\%) are the primary inhibitors of KAL, though they have been demonstrated to have different inhibitory rates as well as different clearance rates. ${ }^{22-24}$

KAL activity is generated in FXII-deficient, but not in PK-deficient plasma when HK-PK complexes assemble on the surface of endothelial cells, and HK serves as both the binding site and cofactor for PK activation. ${ }^{33}$ In this model, a limited amount of KAL is generated in a FXII-independent manner and is subsequently amplified in a FXII-dependent manner. Moreover, KAL generated on the cell surface then cleaves HK, liberating itself from the complex with HK (its captor and native substrate) and thereby generating BK. Distinct from the FXII-dependent pathway, the alternative pathway is believed to occur constitutively in vivo and is responsible for basal BK formation. ${ }^{13,18,32,33}$ Two proteins were proposed to provide the enzymatic impulse for PK activation: both heat shock protein 90 (Hsp90) and the serine enzyme prolylcarboxypeptidase (PRCP) on the surface of endothelial cells have been identified as physiological activators of the KAL/kinin system. ${ }^{18,34,35}$ Hsp90 and PRCP can activate the PK-HK complex in the absence of FXII but in the presence of $\mathrm{Zn}^{2+}$. Notably, HSP90 is very abundant in almost all cell types (2-3\% of total cellular proteins) and can be even more abundantly expressed by tumour cells (up to 7\% of total protein). ${ }^{32,36}$ Moreover, it has been reported that PK can be auto-catalytically cleaved by KAL, in the presence of certain negatively charged surfaces. ${ }^{37}$ As for membrane-mediated activation, apart from endothelial cells, the surfaces of some exogenous microorganisms can also assemble and activate the KAL/kinin system (e.g. the surface of Gram-negative bacteria). ${ }^{38}$

\section{Measuring Activation of the Contact System in Plasma}

Investigation of CS activity can be broadly defined as methods that address the potential for exogenous activation, and those that focus on analysis of in vivo activation. Tools such as clotting assays or substrate cleavage can be used to assess a patient's capacity for CS activation using known initiators, as well as discovery of novel putative physiological activators. Evidence for in vivo activation is predominantly assayed via enzyme-linked immunosorbent assay (ELISA), though Western blot and mass spectrometry have seen specialized use. The most common criticisms applied to these assays are the short half-life of the complexes and the potential for ex vivo activation during collection. Minimization of pre-analytical activation through use of benzamidines or specific CS inhibitors with blood collection ${ }^{39}$ is critical and should be considered in study design, since FXII may be rapidly activated ex vivo by contact with blood drawing equipment. ${ }^{40,41}$ To our knowledge, there are currently no clinically standardized assays to quantify in vivo activation of the CS, presenting an unmet need in cancer-associated thrombosis research.

\section{Clotting Assays}

The activated partial thromboplastin time assay (aPTT) uses an anionic surface to activate FXII following the addition of phospholipid and calcium. Shortened aPTT times (probably driven primarily by elevated FVIII levels) have been linked to an elevated risk of thrombosis, although not specifically in cohorts with cancer. ${ }^{42}$ One-stage clotting assays based on aPTT using deficient plasma may be used to detect FXI and XII activity. A reduction in plasma FXII activity has been regarded as a marker of consumption and, thus, indirect evidence of activation of the CS. ${ }^{43}$ However, given the global nature of the aPTT-based tests, more specific assays are required to probe the role of the contact pathway in disease states, including cancer-associated thrombosis.

\section{Substrate Cleavage/Chromogenic Assays}

Factors XIIa, XIa and KAL are serine proteases and their enzymatic function can be assessed by cleavage of synthetic peptides to generate a chromogenic or fluorogenic signal. The most commonly used substrate is S-2302 (H-D-Pro-PheArg-pNA), which is sensitive to cleavage by FXIla and KAL (with a nearly identical $\mathrm{Km}$ and Kcat), and to a much lesser extent, FXIa. This substrate mimics the last three amino acids in the BK sequence of kininogen, and may therefore be used to address the role of FXIIa and KAL in liberation of BK from HK. These substrates may be used to assay the activation of potential initiators of the CS in plasma, as demonstrated in a recent report describing prostatic tumour cell-derived exosomes (prostasomes). ${ }^{44}$ However, detection of in vivo active enzymes using substrates is not practical nor quantifiable. Furthermore, the cross-reactivity of currently available substrates is problematic; although several more specific substrates for CS enzymes have been developed, the use of specific enzyme inhibitors to minimize the possibility of cross-reactivity should be considered. For example, corn 
trypsin inhibitor (CTI) or soybean trypsin inhibitor (STI) may be added to sodium citrate before blood collection to inhibit FXIIa or KAL, respectively ${ }^{45,46}$ Similarly, ethylenediaminetetraacetic acid (EDTA) will chelate zinc, ${ }^{47}$ a required cation in the contact pathway, ${ }^{48}$ and thus collection of samples in citrate is preferred.

\section{ELISA}

One of the earliest reports identifying the role of the CS in cancer used capture ELISA to quantify CS proteins in a cohort of gastrointestinal cancer patients. ${ }^{49}$ Depending on the targeted epitopes, these assays may not be able to distinguish between zymogen, enzyme or inhibited protein. However, combining this approach with evidence of reduced zymogen activity indicates prior CS activation. ELISAs able to distinguish activation states offer a greater benefit when analysing clinical samples. Originally developed as radioimmunoassays, ${ }^{50}$ these assays have been modified to ELISA formats that detect CS proteins bound to their physiologic inhibitors including C1-inhibitor esterase (C1INH), $\alpha_{1}$-antitrypsin, antithrombin, $\alpha 2$-antiplasmin and $\alpha_{2}$-macroglobulin (-Fig. 2). ELISAs for enzyme-inhibitor complexes have been used in various disease states, although not in the setting of cancer-associated thrombosis, to our knowledge (-Fig. 2).51 Certain reports concluded that circulating complexes do not correlate with disease activity, because of their short half-life. ${ }^{52}$ However, the halflives of these complexes are estimated in the range of 30 to 50 minutes, ${ }^{53}$ which can still detect chronic CS activation. By analogy, thrombin-antithrombin (TAT) complexes have a halflife of $\sim 15$ minutes in plasma, yet are an accepted biomarker of on-going coagulation activation in vivo. ${ }^{54}$ Indeed, investigations in patients with endotoxaemia, myocardial infarction and amyloidosis have revealed measurable changes in contact activation using CS enzyme-inhibitor complexes. ${ }^{39,51,55,56}$ More recently, heavy chain-only nanobodies specific for FXIIa have been used to distinguish not only between the activation states of FXII, but also between the $\alpha$ and $\beta$ isoforms. ${ }^{57}$ Finally, HK can be cleaved by either FXIIa or KAL to release HK fragments. An ELISA has been developed to detect cleaved HK in plasma as a marker of CS activation (via KAL) due to its longer half-life ( $\sim 9$ hours), ${ }^{58}$ but has yet to be applied to cancer-associated thrombosis research.

\section{Western Blot}

An alternative approach for detecting activation of the CS activation in plasma is Western blotting. Here, detection of enzyme-inhibitor complexes or cleavage of HK (an indirect measurement of BK release) provide a semi-quantitative measurement of CS activation. ${ }^{59}$ Western blotting can offer advantages such as the speciation of FXIla ( $\alpha$ or $\beta$ ) when analysed under reducing conditions, or complexes with inhibitors under non-reducing conditions, without using specific monoclonal antibodies or the aforementioned nanobodies. ${ }^{60}$ Detection of heavy chain-only HK by Western blotting has shown sensitivity to concentrations as low as $5 \mathrm{ng} / \mathrm{mL},{ }^{61}$ with discernible differences in the plasma of rodent models of BK-mediated diseases. ${ }^{62}$ However, due to the low throughput of Western blotting, clinical samples are not typically analysed using this approach.

\section{Mass Spectrometry}

The major inflammatory effector of the CS is BK, a 9 amino acid peptide generated from the cleavage of HK by KAL. Detection of BK versus FXIa (or FXIa-inhibitor complex) provides a potentially valuable measurement of the inflammatory versus procoagulant endpoints of CS activation. Unfortunately, BK has a circulating half-life $<20$ seconds $^{63}$ due to its rapid metabolism by angiotensin-converting enzyme I (ACE) in the lungs, which greatly limits its detection when it is generated in vivo. However, mass spectrometry may be used to quantify the major stable metabolite, BK $1-5 .{ }^{64}$ Given the role of BK in tumour progression, ${ }^{65,66}$ and evidence for thrombotic protection in mice deficient in the BK2 receptor, ${ }^{64}$ this underutilized approach should be considered in the evaluation of clinical samples.

\section{Clinical Evidence of Contact System Activation in Cancer}

As already mentioned, early evidence of CS activation in cancer was presented in $1990 .{ }^{49} \mathrm{CS}$ activation was evaluated in 69 patients with gastrointestinal cancer (12 with gastric, 15 with pancreatic and 42 with colon cancer), 33 of who had liver metastases, and in 118 healthy controls recruited from blood donors (- Table 1). Antigen levels of FXII, PK, HK and C1INH were measured by immunochemical assays; activity levels of PK and C1INH were measured by chromogenic assays. Values of FXII, PK, HK and C1INH were expressed as a percentage of human standard plasma pool values. FXII, PK and HK antigens were decreased in patients with gastrointestinal cancer ( $84 \pm 28 \%, 74 \pm 19 \%$ and $86 \pm 14 \%$, respectively) compared with the control group $(94 \pm 27 \%, 88 \pm 18 \%$ and $98 \pm 14 \%$, respectively), but only PK and HK values were statistically different $(p<0.05$ for both). PK activity was significantly decreased compared with controls ( $74 \pm 21 \%$ vs. $101 \pm 17 \%$, $p<0.05)$. C1INH antigen and activity were significantly increased in cancer compared with controls $(p<0.05$ for both comparisons). Interestingly, in the subgroup of patients with metastatic colon cancer, FXII, PK and HK levels were significantly decreased $(78 \pm 18 \%, 75 \pm 13 \%$ and $77 \pm 9 \%$, respectively) compared with controls (all $p<0.05$ ). C1INH was significantly increased both in patients with and without metastases compared with controls in both the immunological and functional assays $(p<0.05)$. The authors concluded that patients with intestinal cancer manifest reduced contact factor levels with markedly elevated inhibitor levels. Battistelli et al measured plasma activities of fibrinogen, FII, FV, FVII, FVIII, FIX, FX, FXI and FXII in 73 patients with non-metastatic colorectal cancer ( 48 colon and 25 rectum) and in 67 matched controls. ${ }^{43}$ They showed that the mean plasma activity of fibrinogen (400 $\pm 113 \mathrm{mg} / \mathrm{dL})$, FVIII $(145 \pm 50 \%)$, FIX $(127 \pm 29 \%)$ and $\mathrm{FV}(131 \pm 65 \%)$ were significantly higher in colorectal cancer patients than in control subjects $(287 \pm 74 \mathrm{mg} / \mathrm{dL}, 92 \pm 35 \%$, $109 \pm 22 \%$ and $108 \pm 35 \%$, respectively), while FVII $(102 \pm 25 \%$ vs. $118 \pm 34 \%, p=0.004)$ and FXII ( $96 \pm 26 \%$ vs. 
Table 1 Studies of contact system activation in patients with cancer

\begin{tabular}{|c|c|c|c|c|c|}
\hline Patients & $\begin{array}{l}\text { Patients/ } \\
\text { controls }\end{array}$ & Cancer subtype & Analytes & Main results & Ref \\
\hline $\begin{array}{l}69 \text { gastrointest- } \\
\text { inal cancer } \\
\text { ( } 33 \text { with liver } \\
\text { metastasis) }\end{array}$ & $69 / 118$ & $\begin{array}{l}12 \text { gastric } \\
15 \text { pancreatic } \\
42 \text { colon }\end{array}$ & $\begin{array}{l}\text { FXII, PK, HK, C1INH } \\
\text { immunological and } \\
\text { functional assays }\end{array}$ & $\begin{array}{l}\text { 1. FXII, PK and HK } \\
\text { activity decreased } \\
\text { 2. C1INH increased } \\
\text { 3. CS activation more } \\
\text { pronounced in patients } \\
\text { with liver metastasis }\end{array}$ & 49 \\
\hline $\begin{array}{l}73 \text { colorectal } \\
\text { cancer without } \\
\text { metastasis }\end{array}$ & $73 / 67$ & $\begin{array}{l}48 \text { colon } \\
25 \text { rectum }\end{array}$ & $\begin{array}{l}\text { Fibrinogen, FII, FV, FVII, } \\
\text { FVIII, FIX, FX, FXI, FXII } \\
\text { activity }\end{array}$ & $\begin{array}{l}\text { 1. FVII and FXII activity } \\
\text { decreased } \\
\text { 2. FVII highly correlated } \\
\text { with FXII }\end{array}$ & 43 \\
\hline $\begin{array}{l}34 \text { cancer } \\
\text { (11 advanced } \\
\text { disease) }\end{array}$ & $34 / N P P$ & $\begin{array}{l}10 \text { lung } \\
11 \text { colon } \\
9 \text { breast } \\
3 \text { pancreatic } \\
1 \text { renal }\end{array}$ & $\begin{array}{l}\text { PK, KAL/protease com- } \\
\text { plexes, HK, C1INH and } \\
\text { C1INH/protease com- } \\
\text { plexes by Western } \\
\text { analysis }\end{array}$ & $\begin{array}{l}\text { 1. Cleaved C1INH and } \\
\text { C1INH/protease com- } \\
\text { plexes, absence of HK, } \\
\text { decreased amounts of } \\
\mathrm{PK} \text {, and KAL/protease } \\
\text { complexes (primarily in } \\
\text { lung cancer patients) } \\
\text { 2. Thrombin generation } \\
\text { correlated with KAL/ } \\
\text { protease complexes }\end{array}$ & 67 \\
\hline $\begin{array}{l}20 \text { prostate } \\
\text { cancer }\end{array}$ & $20 / 20$ & 20 prostate & $\begin{array}{l}\text { FXIla activity, thrombin } \\
\text { generation }\end{array}$ & $\begin{array}{l}\text { Humanized antibody } \\
\text { 3F7 inhibited FXIla } \\
\text { activity and reduced } \\
\text { thrombin generation in } \\
\text { normal plasma samples } \\
\text { spiked with prosta- } \\
\text { somes from pancreatic } \\
\text { cancer patients }\end{array}$ & 44 \\
\hline
\end{tabular}

Abbreviations: C1INH, C1esterase inhibitor; FXII, factor XII; HK, high molecular weight kininogen; KAL, kallikrein; NPP, normal pool plasma; PK, prekallikrein; TF, tissue factor.

$113 \pm 3 \%, p=0.003$ ) levels were significantly decreased. Interestingly, FVII was highly correlated with FXII $(p<0.01)$ only in cancer patients. The authors concluded that decreased FVII and FXII activity may be indices of intravascular coagulation activation in colorectal cancer. More recently, Pan et $\mathrm{al}^{67}$ measured CS activation in 10 lung cancer patient plasmas compared with normal pooled plasma. PK, HK and C1INH were quantified by Western blot. The authors concluded that CS activation was present, as evidenced by cleaved C1INH and $\mathrm{C} 1 \mathrm{INH} /$ protease complex in all 10 patients, with absent HK in 9 patients, decreased amounts of PK in 6 and $\mathrm{KAL} /$ protease complex in 5. Moreover, the authors confirmed the same CS activation pattern in 11 colon, 9 breast, 3 pancreatic and 1 renal cancer patients. In particular, all of the pancreatic cancer patient samples showed an absence of detectable HK, whereas only one of the colon cancer plasmas had undetectable HK, and this occurred in a patient with stage IV disease ( $\mathbf{- T a b l e ~} \mathbf{1}$ ).

\section{Mechanisms of Contact System Activation in Cancer}

Although several observations documenting activation of the CS in different cancers have been published, the responsible mechanism(s) is poorly understood. As previously mentioned, the variety of assays that have been used makes it difficult to compare results. - Table 2 summarizes the reported mechanisms of CS activation in cancer.

\section{Microvesicles}

Microvesicles (MVs) are submicron, lipid bilayer membrane particles, shed by various cells upon activation or apoptosis. Our group and others have described elevated levels of circulating MVs, including exosomes (MVs of 50-100 nm in diameter) derived from tumour and host blood cells types in cancer patients. ${ }^{68-71}$ Cancer chemotherapy can potentially induce MV release from tumour, blood or endothelial cells. ${ }^{72}$ Red cell and platelet transfusions administered to cancer patients are additional sources of MVs. MVs and exosomes may play a major role in tumourigenesis, tumour progression, metastasis and cancer-associated thrombosis. ${ }^{68-71,73,74}$ As already mentioned, the prothrombotic role of MVs has been mainly ascribed to TF-bearing MVs. ${ }^{69,70,75,76}$ However, in a cohort of women with breast cancer, circulating annexin-V positive MVs were elevated and correlated with the stage of the tumour. When analysed according to cellular origin, platelet-derived MVs represented the vast majority (> 80\%); their level correlated with plasma levels of prothrombin fragment 1.2, suggesting a role in systemic hypercoagulability. ${ }^{9}$ In this study, TF-MV levels were very low and not different from that of women with benign breast 
Table 2 Major proposed mechanisms of contact activation in cancer

\begin{tabular}{|c|c|c|}
\hline Cancer type & Mechanism suggested & Ref \\
\hline $\begin{array}{l}\text { Gastrointestinal with or without } \\
\text { liver metastasis; no VTE }\end{array}$ & $\begin{array}{l}\text { 1. Proteolytic enzymes such as plasmin, collagenase and } \\
\text { cathepsin } \\
\text { 2. Kallikrein produced by cancer cells } \\
\text { 3. Imbalance of CS linked with metastatic process }\end{array}$ & 49 \\
\hline Colorectal without metastasis; no VTE & $\begin{array}{l}\text { Intravascular coagulation activation mediated by both } \\
\text { extrinsic and intrinsic pathways }\end{array}$ & 43 \\
\hline Miscellaneous & $\begin{array}{l}\text { 1. High levels of MVs } \\
\text { 2. Prothrombotic role mainly ascribed to TF-bearing MVs } \\
\text { 3. Red blood cell and platelet-derived MVs have been shown } \\
\text { to activate CS }\end{array}$ & $69,70,75,76$ \\
\hline Melanoma cell line & $\begin{array}{l}\text { Exosomes spontaneously released or induced by treatment } \\
\text { with doxorubicin triggered thrombin generation even in the } \\
\text { presence of inhibitory TF antibodies }\end{array}$ & 80 \\
\hline Prostate cancer & $\begin{array}{l}\text { 1. Prostasomes secreted by prostate cancer cells activated } \\
\text { intrinsic pathway via PolyP } \\
\text { 2. Blocking FXIla reduced the prothrombotic potential of } \\
\text { prostasomes }\end{array}$ & 44 \\
\hline Acute myeloid leukaemia & $\begin{array}{l}\text { Increased levels of cell-free plasma DNA indicative of con- } \\
\text { tribution of the contact pathway to systemic coagulation } \\
\text { activation in the total patient cohort and in patients with } \\
\text { lower TF procoagulant activity }\end{array}$ & 85 \\
\hline Breast cancer & $\begin{array}{l}\text { Cell-free DNA released from epirubicin-treated whole blood } \\
\text { significantly elevated thrombin generation in a dose- } \\
\text { dependent manner via activation of the contact pathway }\end{array}$ & 95 \\
\hline Miscellaneous & $\begin{array}{l}\text { 1. Increased plasma } \mathrm{H} 3 \mathrm{Cit} \text { in active cancer with stroke } \\
\text { compared with stroke without cancer } \\
\text { 2. H3Cit positively correlated with plasma TAT }\end{array}$ & 102 \\
\hline Miscellaneous & $\begin{array}{l}\text { 1. High GAGs (glucosamine and galactosamine) levels } \\
\text { expressed by tumoural tissue (mainly lung) or by } \\
\text { endothelial cells may activate CS } \\
\text { 2. Carcinoma mucins may induce CS activation }\end{array}$ & 67 \\
\hline
\end{tabular}

Abbreviations: CS, contact system; F, factor; GAGs, glycosaminoglycans; H3Cit, citrullinated histone H3; MVs, microvesicles; PolyP, polyphosphate; TAT, thrombin-antithrombin complexes; TF, tissue factor; VTE, venous thromboembolism.

tumours, although the correlation with prothrombin fragment was seen only in patients with metastatic cancer. ${ }^{9}$ Red blood cell and platelet-derived MVs have previously been shown to activate coagulation through the contact pathway in the context of blood product storage and human endotoxaemia, although here again, the precise molecular trigger for this event remains to be determined. ${ }^{77-79}$ In addition to blood cell-derived MVs, certain tumour-derived exosomes have also been shown to interact with the CS. Exosomes spontaneously released or induced by treatment of the B16 melanoma cell line with doxorubicin in vitro, triggered thrombin and fibrin generation in plasma in the presence of inhibitory TF antibodies. ${ }^{80}$ In a mouse model of breast cancer, tumour-derived exosomes cooperated with neutrophils primed by tumour-derived G-CSF to generate NETs and enhance thrombosis (further discussed below). ${ }^{81}$ Additionally, exosomes secreted by prostate cancer cells (prostasomes) trigger thrombin generation in vitro in a dosedependent manner, and induce lethal pulmonary embolism in mice. ${ }^{44}$ Moreover, the addition of a recombinant FXIIa inhibitor significantly reduced peak and total thrombin generated by prostasomes, and the combined application of FXIIa and TF inhibitors completely blunted thrombin generation. Polyphosphates were found on the surface of prostasomes. Treatment of prostasomes with specific inhibitors of polyphosphates or with polyphosphate degrading enzymes abrogated prostasome-induced FXIla generation in vitro and protected mice from prostasome-induced lethal pulmonary embolism. However, since similar effects were also observed following inhibition of TF, both the intrinsic and extrinsic pathways seemed to contribute to thrombosis in this model. Further data are required in a diverse range of cancers to understand the role that circulating exosomes/ MVs may play in CS activation.

\section{Cell-Free DNA, Histones and Neutrophil Extracellular Traps}

Elevated circulating levels of cell-free DNA (cfDNA) and histones, the major molecular components in nucleosomes/chromatin, are found in cancer patients. They are associated with adverse outcomes and are positively correlated with markers of in vivo coagulation activation such as plasma TAT and D-dimer levels. ${ }^{82-85}$ The mechanisms of extracellular release and the cellular origin of cfDNA and 
histones are unclear, and probably vary according to tumour type, patient co-morbidities and chemotherapy. In cancer patients, cfDNA may be either tumour-derived or released from apoptotic or necrotic non-tumoural tissues, such as neutrophils. ${ }^{86}$ Cancer chemotherapy is associated with increased plasma levels of cfDNA. ${ }^{87-89}$ Multiple groups, including our own, have reported FXII-dependent procoagulant activity of purified DNA in vitro. ${ }^{90-94}$ Specifically, Swystun et $\mathrm{al}^{95}$ showed that cfDNA purified from epirubicin-treated whole blood ex vivo significantly elevated thrombin generation in a dose-dependent manner by a mechanism involving activation of the contact pathway. Purified histones promote platelet activation and aggregation, and trigger thrombin generation in a platelet-dependent manner. ${ }^{96,97}$ They also induce phosphatidylserine expression on red blood cells and impair thrombomodulin-dependent protein $\mathrm{C}$ activation, leading to enhanced thrombin generation in plasma ex vivo. ${ }^{98,99}$ Noteworthy, it is unclear if DNA and histones circulate in their free forms. It is also unknown if DNA or histones bound to other blood components affect their respective procoagulant activities observed in vitro.

Cancer cells secrete various types of cytokines that modify neutrophil biology, leading to changes in neutrophil counts and state of activation, including the release of neutrophil extracellular traps (NETs). ${ }^{81,100,101}$ Animal models have suggested that NETosis plays a major role in cancerassociated thrombosis. In a mouse model of mammary carcinoma, tumour-bearing mice developed a leukaemoid reaction and spontaneous delayed onset thrombosis within the lungs. Interestingly, the percentage of circulating hypercitrullinated neutrophils increased at day 21 post-tumour injection and decreased at the time that thrombosis occurred. Furthermore, the disappearance of hypercitrullinated neutrophils from the circulation coincided with the appearance of hypercitrullinated histone $\mathrm{H} 3$ (H3Cit) in the plasma of these mice. ${ }^{101}$ Hypercitrullination of histones, which is believed to be mediated by neutrophil PADI4 enzyme, has been proposed to be a specific marker of NETosis. Hence, the observations in this model were thought to indicate a major role of tumour-induced NETs in cancer-associated thrombosis. In another study, orthotopic injection of the same cancer cell line into mice led to rapid development of metastases. Tumour-bearing mice exhibited a reduced time to jugular vein occlusion during venous thrombosis induced by Rose Bengal/laser photochemical injury compared with control mice, as well as reduction in time to arterial occlusion triggered in the carotid artery by ferric chloride injury. Pre-treatment of mice with DNAse 1 abolished the differences between tumour-bearing and control mice during both venous and arterial thrombosis challenges, further suggesting a role of NETs in these models of cancer-associated thrombosis. ${ }^{81}$ In humans, Thålin et al reported a significantly higher level of plasma H3Cit in patients with active cancer and stroke than in patients with stroke without active cancer. In this study, plasma level of H3Cit positively correlated with plasma TAT, supporting a possible link between NETosis and cancer-asso- ciated thrombosis. ${ }^{102}$ However, the mechanisms by which NETs promote thrombosis are not fully understood and are likely multifactorial. NETs released intravascularly adhere to the vessel wall, where they resist flow and trap suspended and soluble components of the blood, including those of the clotting system. ${ }^{90,96,103,104}$ In this way, NETs facilitate interactions between coagulation components, enhance thrombin generation and increase thrombus size. These prothrombotic properties can be abrogated by preventing NET formation or by dismantling the NET scaffold, using DNAse 1 , for example. ${ }^{81,104}$ However, whether the intact NET macromolecular structure directly activates coagulation is controversial. In cancer, MVs, activated leucocytes and/or cancer cells themselves can provide circulating TF, which are trapped on NETs. Neutrophil elastase, an enzyme abundant in neutrophil cytoplasmic granules and in extruded NETs, has been shown to enhance thrombosis by inhibiting TF pathway inhibitor. ${ }^{105}$ Deficiency in FXII does not confer protection from thrombus formation in NET-dependent animal models of thrombosis. ${ }^{106}$ Several studies have reported CS activation using thrombin generation in platelet-poor plasma containing NETs generated ex vivo. ${ }^{90,91,107}$ However, in the presence of intact NETs, we did not observe any thrombin generation in platelet-free plasma, or in a purified CS reconstituted in buffer. ${ }^{92}$

\section{Activated Platelets}

There is an extensive literature on the multiple roles of activated platelets in cancer-associated thrombosis. ${ }^{108}$ Activation of the CS by activated platelets has been observed since the early 1980s. ${ }^{109}$ Activated platelets can expose membrane-bound divalent ion-complexed polyphosphate nanoparticles, which resist circulating polyphosphatases and trigger FXII activation. ${ }^{31}$ Released platelet polyphosphates have also been reported to activate the CS in vitro and in vivo. ${ }^{28,110} \mathrm{~A}$ recent study by Riedl et al demonstrated platelet activation mediated by expression of podoplanin by brain tumours, ${ }^{111}$ likely through CLEC-2 signalling. ${ }^{112}$ However, whether tumour-podoplanin-CLEC-2-mediated platelet axis promotes thrombosis through CS activation has not been evaluated.

\section{Glycosaminoglycans}

At a molecular level, certain GAG species have been shown to activate FXII and the KAL-kinin pathway, with adverse clinical outcomes; the most notable example was when heparin batches contaminated by hypersulphated chondroitin sulphate moieties were inadvertently administered to patients. $^{25}$ Whether tumour cells can similarly produce atypical GAGs that activate the CS is unclear. Pan et al measured levels of glucosamine- and galactosamine-containing glycans as a putative mechanism for CS activation in cancer patients. ${ }^{67}$ Galactosamine levels were increased in lung cancer but not in breast or pancreatic cancer patients compared with controls; on the other hand, glucosamine levels were increased in both lung and breast cancer patients compared with controls, although this was not observed in pancreatic cancer (-Table 2 ). 


\section{Catheter-Related Thrombosis}

The use of venous catheters to facilitate chemotherapy, transfusions, parenteral nutrition and blood sampling is common in cancer patients. Up to 66 and 50\% of patients with cancer and indwelling catheters develop insertion site thrombosis or pulmonary embolism, respectively. ${ }^{113,114}$ Reported risk factors for catheter-related thrombosis (CRT) in cancer patients include left-sided or superior vena cava insertion, chest radiotherapy, metastasis and elevated homocysteine levels. ${ }^{115}$ The mechanisms by which catheters promote thrombosis are incompletely understood. Vessel injury and stasis caused by catheter insertion, cancer-induced 'hypercoagulability' and other comorbidities can all contribute to thrombosis. ${ }^{115}$ Additionally, materials used to construct medical devices are inherently procoagulant to a greater or lesser extent. In contrast to the healthy endothelium, which actively resists thrombosis, artificial surfaces promote clotting through a complex series of interconnected processes that include protein adsorption and platelet and leukocyte adhesion and activation that ultimately leads to fibrin formation. ${ }^{116}$ CS proteins including FXII, PK, HK and FXI adsorb to artificial surfaces, ${ }^{117}$ and catheter segments shorten clotting times when introduced in re-calcified plasma ex vivo. This procoagulant effect is attenuated in the presence of CTI, and is abolished in FXII- or FXI-deficient plasma, indicating that clotting is mediated by CS activation. ${ }^{118}$ Furthermore, contact of whole blood with some materials used to manufacture medical devices induces TF expression on monocytes and TF-dependent shortening of clotting time ex vivo. ${ }^{17}$ Since monocytes adhere to catheter surfaces, it is therefore possible that activation of the extrinsic pathway also contributes to CRT. While the relative contribution of the intrinsic versus the extrinsic pathway is unknown, one can speculate that these two pathways act synergistically to promote CRT, especially in the context of cancer where circulating TF is likely to be present. ${ }^{19,120}$

\section{Therapeutic Implications of Contact System Activation in Cancer}

Current practice recommends the use of heparins for the treatment and prophylaxis of VTE, as well as the treatment of symptomatic CRT in patients with cancer. ${ }^{121}$ These treatments are associated with bleeding side effects, which can be of major concern in patients with chemotherapyinduced thrombocytopenia, and in certain cancer types associated with a high risk of bleeding. The use of anticoagulation for routine prophylaxis of CRT is not recommended, as it largely fails to prevent CRT occurrence. ${ }^{115}$ Additionally, manufacturing catheters using biomaterials that are less thrombogenic would help to further reduce the incidence of CRT. Indeed, coating catheters with polyethylene glycol and CTI reduced protein adhesion, the ability to trigger FXII-dependent coagulation activation in plasma and a 2.5 -fold prolongation of time to occlusion when inserted in the jugular vein of rabbits. ${ }^{119,122}$ Other coating compounds, including heparins, direct thrombin inhibitors and thrombomodulin, have shown promising results in reducing the thrombogenicity of materials used to make medical devices in vitro, though available data in vivo are limited. ${ }^{116}$ Interestingly, it seems that anticoagulant agents that target serine proteases of the common pathway (FXa and thrombin) have limited capacity to prevent medical device-induced thrombosis in vivo and ex vivo. ${ }^{118,123}$ It has been postulated that medical devicedriven CS activation generates FXa and thrombin in concentrations that overcome the inhibition by therapeutic doses of FXa and thrombin inhibitors. ${ }^{116}$ Using agents that inhibit CS activation might provide more efficient anticoagulation. However, further studies are required to evaluate the use of CS inhibitors for the prevention of medical device-induced thrombosis in clinical settings.

Although more evidence from basic, translational and clinical research is required, the potential contribution of CS activation in non-CRT thrombosis in cancer opens the door to novel therapeutic possibilities. Inhibition of the CS may protect against thrombosis without increasing the risk of bleeding, as previously shown by genetic or pharmacologic inhibition of FXIla in animals. ${ }^{124}$ Several classes of CS inhibitors are under development as thromboprotective and/or anti-inflammatory agents ${ }^{125-147}$ (-Table 3). Most of these agents have shown ability to inhibit CS in vitro or in experimental models of thrombosis in animals without cancer. Conceptually, targeting FXII or FXIIa would be reasonable in settings where CS activation is the dominant mechanism of coagulation activation. As mentioned above, circulating TF is present in many cancers. TF is very efficient at initiating coagulation, but is also efficiently inhibited by TFPI. ${ }^{148}$ Thrombus formation then relies on the contribution of the intrinsic pathway for subsequent thrombin generation. This can be achieved by FXIIa formation that will then activate FXI, or by the feedback activation of FXI by thrombin. Consequently, FXI or FXIa are good targets to interrupt the additive or synergistic effects of activation of both the extrinsic and intrinsic pathways. Moreover, such an approach seems to represent a reasonable compromise between preventing thrombosis with a lower risk of bleeding compared with commonly used heparins. For instance, reducing plasma FXI to $20 \%$ of normal levels using an antisense oligonucleotide (ASO ISIS-416858) was more effective than low molecular weight heparin in preventing VTE following knee replacement surgery, without any increase in intraoperative or postoperative bleeding. ${ }^{126,143,144}$ To date, no clinical trial has evaluated therapies targeting FXI/XIa to prevent thrombosis in the context of cancer.

Systemic administration of DNAse confers protection against experimental models of cancer-associated thrombosis. ${ }^{81}$ Thus, DNAse I represents a potential candidate for the prevention or treatment of thrombosis, as it does not directly affect haemostasis. However, convincing evidence supporting the contribution of NETs to human thrombosis, and clinical experience with systemic administration of DNAse I in humans are lacking, although recombinant DNAse I aerosol is used in humans with cystic fibrosis. ${ }^{147}$ 


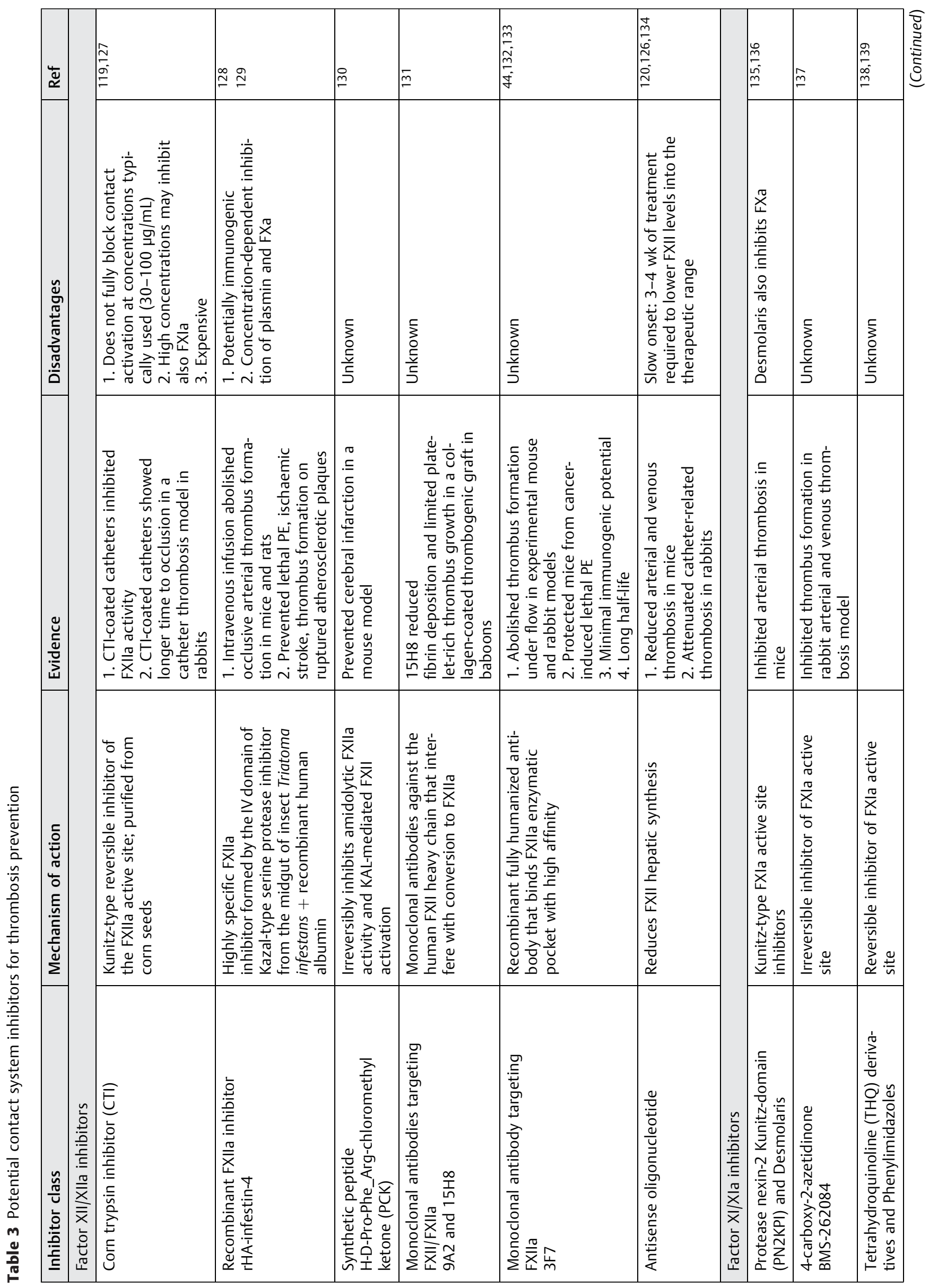




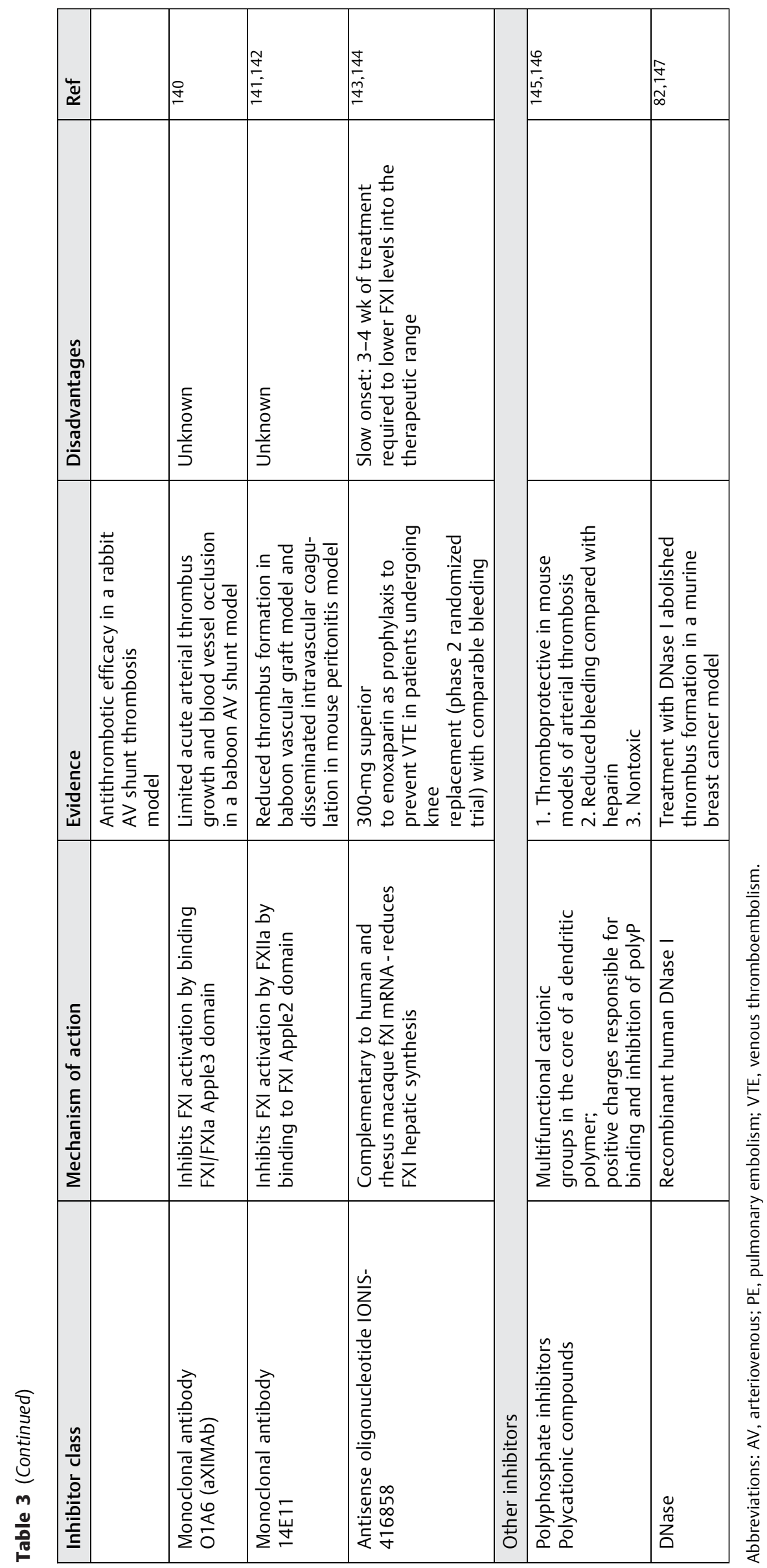

Thrombosis and Haemostasis Vol. 118 No. 2/2018 


\section{Conclusion}

Increasing interest in the contact pathway of coagulation has focused on a possible role in the pathogenesis of thrombosis. Preliminary observations have noted the presence of activation of the CS in gastrointestinal, lung, breast and prostate cancers. However, assays used to measure CS activation differed among studies. A standardized approach that would best quantify in vivo CS activation in clinical samples has yet to be developed. Several candidates that are known to activate the CS in vitro are found in the circulation of patients with cancer. However, further research is needed to establish what biological surfaces or molecular component(s) promote CS activation in human cancer. It is possible that the surface varies with the type of tumour. For instance, polyphosphate-bearing prostasomes seem to be a candidate in prostate cancer. More studies are required to understand if the type, stage, grade and treatment of cancer modulate CS activation. Although NETosis appears to play a role in cancerassociated thrombosis in animals, it remains unclear if this effect is due to direct CS activation. As TF is up-regulated in many cancers, it seems reasonable to propose that concomitant activation of both the intrinsic and extrinsic pathways acts synergistically to produce a highly prothrombotic state in cancer ( $\mathbf{F i g . 3}$ ). It is tempting to speculate that while TF is the primary initiator, CS activation contributes to the amplification of thrombin generation. Future research should focus primarily on the standardization of methods to measure CS in clinical samples. This advance would further our understanding of the mechanisms by which CS activation contributes to non-CRT in humans. For CRT where CS activation is thought to play a major role, novel

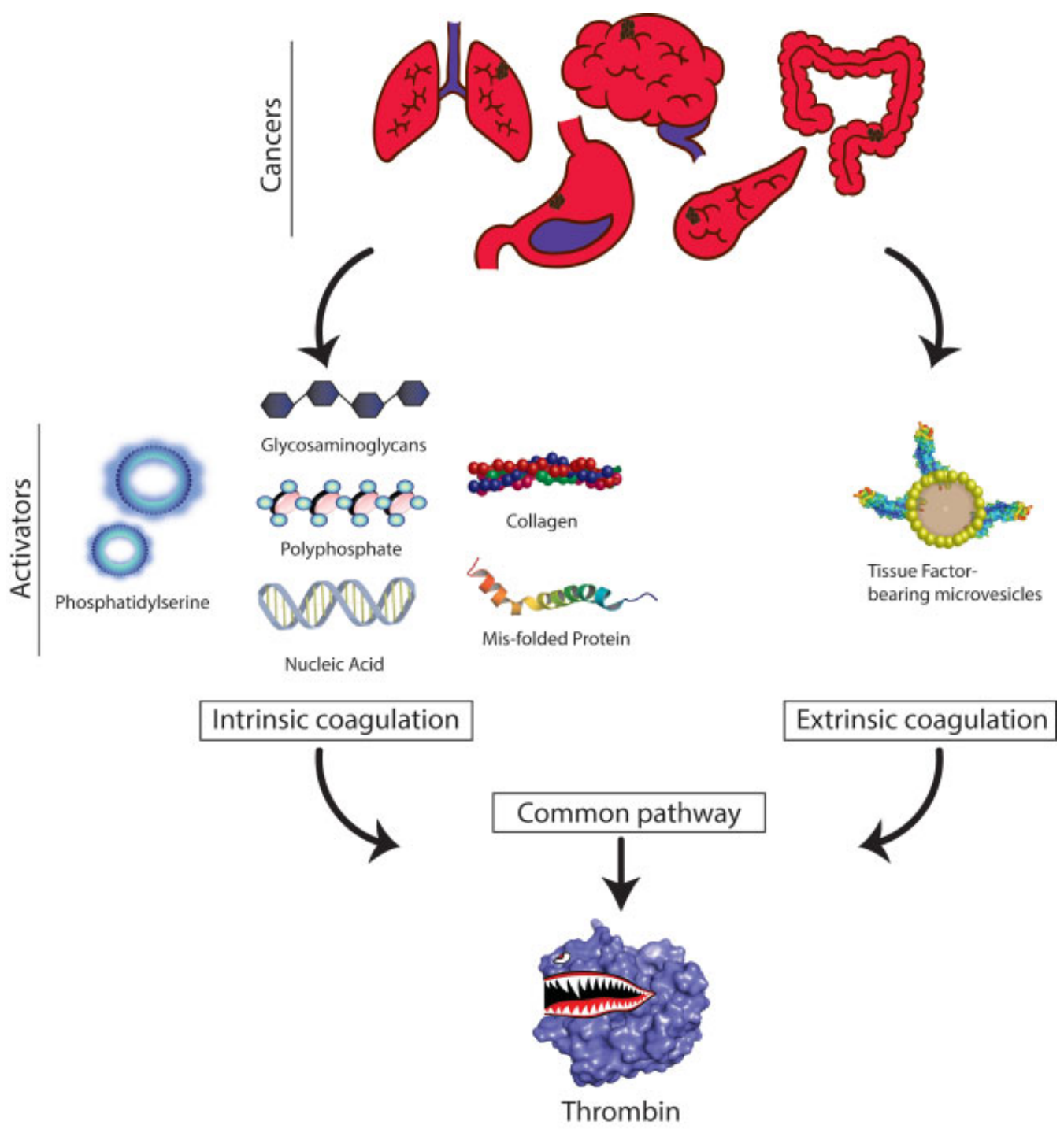

Fig. 3 Molecular activators of coagulation in cancer. Coagulation activation in cancer-associated thrombosis may be explained by contributions from both the tissue factor ('extrinsic') and FXII/FXI-dependent ('intrinsic') pathways. Tissue factor-bearing microvesicles may be released into the circulation by various tumour types and promote thrombin generation and ultimately thrombosis. FXII may be activated in vivo by a variety of negatively charged molecules. These could include phosphatidylserine (e.g. on microvesicles), glycosaminoglycans, polyphosphate, collagen, nucleic acids and misfolded proteins. Activation of the contact system in cancer would promote the generation of thrombin, thereby exacerbating thrombotic risk. 
therapeutic options targeting contact pathways should be evaluated in well-designed clinical trials.

Conflict of Interest

None declared.

Acknowledgements

Support from the ISTH Training Fellowship Program (to EC) is gratefully acknowledged. NSK was supported by NIH grant R01-HL095096.

\section{References}

1 Trousseau A. Phlegmasia alba dolens. Clin Med Hotel-dieu Paris 1865;3:654-712

2 Varki A. Trousseau's syndrome: multiple definitions and multiple mechanisms. Blood 2007;110(06):1723-1729

3 Elyamany G, Alzahrani AM, Bukhary E. Cancer-associated thrombosis: an overview. Clin Med Insights Oncol 2014;8:129-137

4 Khorana AA. Cancer-associated thrombosis: updates and controversies. Hematology (Am Soc Hematol Educ Program) 2012; 2012:626-630

5 Timp JF, Braekkan SK, Versteeg HH, Cannegieter SC. Epidemiology of cancer-associated venous thrombosis. Blood 2013;122 (10):1712-1723

6 Cohen AT, Katholing A, Rietbrock S, Bamber L, Martinez C. Epidemiology of first and recurrent venous thromboembolism in patients with active cancer. A population-based cohort study. Thromb Haemost 2017;117(01):57-65

7 Khorana AA, Ahrendt SA, Ryan CK, et al. Tissue factor expression, angiogenesis, and thrombosis in pancreatic cancer. Clin Cancer Res 2007;13(10):2870-2875

8 Wang JG, Geddings JE, Aleman MM, et al. Tumor-derived tissue factor activates coagulation and enhances thrombosis in a mouse xenograft model of human pancreatic cancer. Blood 2012;119 (23):5543-5552

9 Toth B, Liebhardt S, Steinig K, et al. Platelet-derived microparticles and coagulation activation in breast cancer patients. Thromb Haemost 2008;100(04):663-669

10 Thaler J, Ay C, Mackman N, et al. Microparticle-associated tissue factor activity, venous thromboembolism and mortality in pancreatic, gastric, colorectal and brain cancer patients. J Thromb Haemost 2012;10(07):1363-1370

11 Hernández C, Orbe J, Roncal C, et al. Tissue factor expressed by microparticles is associated with mortality but not with thrombosis in cancer patients. Thromb Haemost 2013;110(03): 598-608

12 Maas C, Oschatz C, Renné T. The plasma contact system 2.0. Semin Thromb Hemost 2011;37(04):375-381

13 Schmaier $\mathrm{AH}$. The contact activation and kallikrein/kinin systems: pathophysiologic and physiologic activities. J Thromb Haemost 2016;14(01):28-39

14 de Maat S, Maas C. Factor XII: form determines function. J Thromb Haemost 2016;14(08):1498-1506

15 Long AT, Kenne E, Jung R, Fuchs TA, Renné T. Contact system revisited: an interface between inflammation, coagulation, and innate immunity. J Thromb Haemost 2016;14(03): 427-437

16 de Maat S, Tersteeg C, Herczenik E, Maas C. Tracking down contact activation - from coagulation in vitro to inflammation in vivo. Int J Lab Hematol 2014;36(03):374-381

17 Renné T, Schmaier AH, Nickel KF, Blombäck M, Maas C. In vivo roles of factor XII. Blood 2012;120(22):4296-4303

18 Lin L, Wu M, Zhao J. The initiation and effects of plasma contact activation: an overview. Int J Hematol 2017;105(03):235-243
19 Schapira M. Major inhibitors of the contact phase coagulation factors. Semin Thromb Hemost 1987;13(01):69-78

20 Pixley RA, Schapira M, Colman RW. The regulation of human factor XIla by plasma proteinase inhibitors. J Biol Chem 1985;260 (03):1723-1729

21 Wuillemin WA, Minnema M, Meijers JC, et al. Inactivation of factor XIa in human plasma assessed by measuring factor XIaprotease inhibitor complexes: major role for C1-inhibitor. Blood 1995;85(06):1517-1526

22 van der Graaf F, Koedam JA, Bouma BN. Inactivation of kallikrein in human plasma. J Clin Invest 1983;71(01):149-158

23 Schapira M, Scott CF, Colman RW. Contribution of plasma protease inhibitors to the inactivation of kallikrein in plasma. J Clin Invest 1982;69(02):462-468

24 Kaufman N, Page JD, Pixley RA, Schein R, Schmaier AH, Colman RW. Alpha 2-macroglobulin-kallikrein complexes detect contact system activation in hereditary angioedema and human sepsis. Blood 1991;77(12):2660-2667

25 Kishimoto TK, Viswanathan K, Ganguly T, et al. Contaminated heparin associated with adverse clinical events and activation of the contact system. N Engl J Med 2008;358(23):2457-2467

26 Morrissey JH, Choi SH, Smith SA. Polyphosphate: an ancient molecule that links platelets, coagulation, and inflammation. Blood 2012;119(25):5972-5979

27 Kornberg A, Rao NN, Ault-Riché D. Inorganic polyphosphate: a molecule of many functions. Annu Rev Biochem 1999; 68:89-125

28 Smith SA, Mutch NJ, Baskar D, Rohloff P, Docampo R, Morrissey $\mathrm{JH}$. Polyphosphate modulates blood coagulation and fibrinolysis. Proc Natl Acad Sci U S A 2006;103(04):903-908

29 Smith SA, Choi SH, Davis-Harrison R, et al. Polyphosphate exerts differential effects on blood clotting, depending on polymer size. Blood 2010;116(20):4353-4359

30 Donovan AJ, Kalkowski J, Smith SA, Morrissey JH, Liu Y. Sizecontrolled synthesis of granular polyphosphate nanoparticles at physiologic salt concentrations for blood clotting. Biomacromolecules 2014;15(11):3976-3984

31 Verhoef JJ, Barendrecht AD, Nickel KF, et al. Polyphosphate nanoparticles on the platelet surface trigger contact system activation. Blood 2017;129(12):1707-1717

32 de Maat S, de Groot PG, Maas C. Contact system activation on endothelial cells. Semin Thromb Hemost 2014;40(08):887894

33 Motta G, Rojkjaer R, Hasan AAK, Cines DB, Schmaier AH. High molecular weight kininogen regulates prekallikrein assembly and activation on endothelial cells: a novel mechanism for contact activation. Blood 1998;91(02):516-528

34 Joseph K, Tholanikunnel BG, Kaplan AP. Heat shock protein 90 catalyzes activation of the prekallikrein-kininogen complex in the absence of factor XII. Proc Natl Acad Sci U S A 2002;99(02): 896-900

35 Shariat-Madar Z, Mahdi F, Schmaier AH. Identification and characterization of prolylcarboxypeptidase as an endothelial cell prekallikrein activator. J Biol Chem 2002;277(20): 17962-17969

36 Li W, Sahu D, Tsen F. Secreted heat shock protein-90 (Hsp90) in wound healing and cancer. Biochim Biophys Acta 2012;1823 (03):730-741

37 Tans G, Rosing J, Berrettini M, Lämmle B, Griffin JH. Autoactivation of human plasma prekallikrein. J Biol Chem 1987;262(23): 11308-11314

38 Herwald H, Mörgelin M, Olsén A, et al. Activation of the contactphase system on bacterial surfaces-a clue to serious complications in infectious diseases. Nat Med 1998;4(03):298-302

39 Minnema MC, Pajkrt D, Wuillemin WA, et al. Activation of clotting factor XI without detectable contact activation in experimental human endotoxemia. Blood 1998;92(09):3294-3301 
40 Ramström S. Clotting time analysis of citrated blood samples is strongly affected by the tube used for blood sampling. Blood Coagul Fibrinolysis 2005;16(06):447-452

41 Boknäs N, Faxälv L, Lindahl TL, Ramström S. Contact activation: important to consider when measuring the contribution of tissue factor-bearing microparticles to thrombin generation using phospholipid-containing reagents. J Thromb Haemost 2014;12(04):515-518

42 Weng LC, Cushman M, Pankow JS, et al. A genetic association study of activated partial thromboplastin time in European Americans and African Americans: the ARIC Study. Hum Mol Genet 2015;24(08):2401-2408

43 Battistelli S, Stefanoni M, Lorenzi B, et al. Coagulation factor levels in non-metastatic colorectal cancer patients. Int J Biol Markers 2008;23:36-41

44 Nickel KF, Ronquist G, Langer F, et al. The polyphosphate-factor XII pathway drives coagulation in prostate cancer-associated thrombosis. Blood 2015;126(11):1379-1389

45 Røjkjaer R, Hasan AA, Motta G, Schousboe I, Schmaier AH. Factor XII does not initiate prekallikrein activation on endothelial cells. Thromb Haemost 1998;80(01):74-81

46 Rao GJ, Posner LA, Nadler HL. Deficiency of kallikrein activity in plasma of patients with cystic fibrosis. Science 1972;177 (4049):610-611

47 Nyborg JK, Peersen OB. That zincing feeling: the effects of EDTA on the behaviour of zinc-binding transcriptional regulators. Biochem J 2004;381(Pt 3):e3-e4

48 Shibayama Y, Joseph K, Nakazawa Y, Ghebreihiwet B, Peerschke EI, Kaplan AP. Zinc-dependent activation of the plasma kininforming cascade by aggregated beta amyloid protein. Clin Immunol 1999;90(01):89-99

49 Roeise O, Sivertsen S, Ruud TE, Bouma BN, Stadaas JO, Aasen AO. Studies on components of the contact phase system in patients with advanced gastrointestinal cancer. Cancer 1990;65(06): 1355-1359

50 Nuijens JH, Huijbregts CC, Cohen M, et al. Detection of activation of the contact system of coagulation in vitro and in vivo: quantitation of activated Hageman factor-C-1-inhibitor and kallikrein-C-1-inhibitor complexes by specific radioimmunoassays. Thromb Haemost 1987;58(02):778-785

51 Konings J, Govers-Riemslag JW, Spronk HM, Waltenberger JL, ten Cate H. Activation of the contact system in patients with a first acute myocardial infarction. Thromb Res 2013;132(01):138142

52 Wuillemin WA, Hack CE, Bleeker WK, Biemond BJ, Levi M, ten Cate $\mathrm{H}$. Inactivation of factor Xia in vivo: studies in chimpanzees and in humans. Thromb Haemost 1996;76(04):549-555

53 Minnema MC, Wittekoek ME, Schoonenboom N, Kastelein JJ, Hack CE, ten Cate H. Activation of the contact system of coagulation does not contribute to the hemostatic imbalance in hypertriglyceridemia. Arterioscler Thromb Vasc Biol 1999;19(10): 2548-2553

54 Siegerink B, Govers-Riemslag JW, Rosendaal FR, Ten Cate H, Algra A. Intrinsic coagulation activation and the risk of arterial thrombosis in young women: results from the Risk of Arterial Thrombosis in relation to Oral contraceptives (RATIO) case-control study. Circulation 2010;122(18):1854-1861

55 Maas C, Govers-Riemslag JW, Bouma B, et al. Misfolded proteins activate factor XII in humans, leading to kallikrein formation without initiating coagulation. J Clin Invest 2008;118(09): 3208-3218

56 Lee SY, Niikura T, Iwakura T, Sakai Y, Kuroda R, Kurosaka M. Thrombin-antithrombin III complex tests. J Orthop Surg (Hong Kong) 2017;25(01):170840616684501

57 de Maat S, van Dooremalen S, de Groot PG, Maas C. A nanobodybased method for tracking factor XII activation in plasma. Thromb Haemost 2013;110(03):458-468
58 Hofman ZLM, de Maat S, Suffritti C, et al. Cleaved kininogen as a biomarker for bradykinin release in hereditary angioedema. J Allergy Clin Immunol 2017;140(06):1700-1703

59 Joseph K, Tholanikunnel BG, Kaplan AP. Factor XII-independent cleavage of high-molecular-weight kininogen by prekallikrein and inhibition by C1 inhibitor. J Allergy Clin Immunol 2009;124 (01):143-149

60 Madsen DE, Sidelmann JJ, Overgaard K, Koch C, Gram JB. ELISA for determination of total coagulation factor XII concentration in human plasma. J Immunol Methods 2013;394(12):32-39

61 Zini JM, Schmaier AH, Cines DB. Bradykinin regulates the expression of kininogen binding sites on endothelial cells. Blood 1993; 81(11):2936-2946

62 Stadnicki A, Sartor RB, Janardham R, et al. Kallikrein-kininogen system activation and bradykinin (B2) receptors in indomethacin induced enterocolitis in genetically susceptible Lewis rats. Gut 1998;43(03):365-374

63 Murphey LJ, Gainer JV, Vaughan DE, Brown NJ. Angiotensinconverting enzyme insertion/deletion polymorphism modulates the human in vivo metabolism of bradykinin. Circulation 2000; 102(08):829-832

64 Murphey LJ, Hachey DL, Vaughan DE, Brown NJ, Morrow JD. Quantification of BK1-5, the stable bradykinin plasma metabolite in humans, by a highly accurate liquid-chromatographic tandem mass spectrometric assay. Anal Biochem 2001;292 (01):87-93

65 Yu HS, Wang SW, Chang AC, et al. Bradykinin promotes vascular endothelial growth factor expression and increases angiogenesis in human prostate cancer cells. Biochem Pharmacol 2014;87 (02):243-253

66 Cuddapah VA, Turner KL, Seifert S, Sontheimer H. Bradykinininduced chemotaxis of human gliomas requires the activation of KCa3.1 and ClC-3. J Neurosci 2013;33(04):1427-1440

67 Pan J, Qian Y, Weiser P, et al. Glycosaminoglycans and activated contact system in cancer patient plasmas. Prog Mol Biol Transl Sci 2010;93:473-495

68 Zhang X, Yuan X, Shi H, Wu L, Qian H, Xu W. Exosomes in cancer: small particle, big player. J Hematol Oncol 2015;8:83

69 Campello E, Spiezia L, Radu CM, et al. Endothelial, platelet, and tissue factor-bearing microparticles in cancer patients with and without venous thromboembolism. Thromb Res 2011;127(05): 473-477

70 Sartori MT, Della Puppa A, Ballin A, et al. Circulating microparticles of glial origin and tissue factor bearing in high-grade glioma: a potential prothrombotic role. Thromb Haemost 2013;110(02):378-385

71 Zhao L, Bi Y, Kou J, Shi J, Piao D. Phosphatidylserine exposingplatelets and microparticles promote procoagulant activity in colon cancer patients. J Exp Clin Cancer Res 2016; 35:54

72 Lechner D, Weltermann A. Chemotherapy-induced thrombosis: a role for microparticles and tissue factor? Semin Thromb Hemost 2008;34(02):199-203

73 Mezouar S, Mege D, Darbousset R, et al. Involvement of plateletderived microparticles in tumor progression and thrombosis. Semin Oncol 2014;41(03):346-358

74 Żmigrodzka M, Guzera M, Miśkiewicz A, Jagielski D, Winnicka A. The biology of extracellular vesicles with focus on platelet microparticles and their role in cancer development and progression. Tumour Biol 2016;37(11):14391-14401

75 Geddings JE, Mackman N. Tumor-derived tissue factor-positive microparticles and venous thrombosis in cancer patients. Blood 2013;122(11):1873-1880

76 Geddings JE, Hisada Y, Boulaftali Y, et al. Tissue factor-positive tumor microvesicles activate platelets and enhance thrombosis in mice. J Thromb Haemost 2016;14(01):153-166 
77 Van Der Meijden PE, Van Schilfgaarde M, Van Oerle R, Renné T, ten Cate H, Spronk HM. Platelet- and erythrocyte-derived microparticles trigger thrombin generation via factor XIIa. J Thromb Haemost 2012;10(07):1355-1362

78 Rubin O, Delobel J, Prudent M, et al. Red blood cell-derived microparticles isolated from blood units initiate and propagate thrombin generation. Transfusion 2013;53(08):1744-1754

79 Mooberry MJ, Bradford R, Hobl EL, Lin FC, Jilma B, Key NS. Procoagulant microparticles promote coagulation in a factor XI-dependent manner in human endotoxemia. J Thromb Haemost 2016;14(05):1031-1042

80 Muhsin-Sharafaldine MR, Saunderson SC, Dunn AC, Faed JM, Kleffmann T, McLellan AD. Procoagulant and immunogenic properties of melanoma exosomes, microvesicles and apoptotic vesicles. Oncotarget 2016;7(35):56279-56294

81 Leal AC, Mizurini DM, Gomes T, et al. Tumor-derived exosomes induce the formation of neutrophil extracellular traps: implications for the establishment of cancer-associated thrombosis. Sci Rep 2017;7(01):6438

82 Holdenrieder S, Stieber P, Förg T, et al. Apoptosis in serum of patients with solid tumours. Anticancer Res 1999;19 (4A):2721-2724

83 Yi Z, Liu B, Guan X, Ma F. Plasma cell-free DNA and survival in non-small-cell lung cancer: a meta-analysis. Mol Clin Oncol 2017;7(02):167-172

84 Spindler KG, Boysen AK, Pallisgård N, et al. Cell-free DNA in metastatic colorectal cancer: a systematic review and metaanalysis. Oncologist 2017;22(09):1049-1055

85 Dicke C, Amirkhosravi A, Spath B, et al. Tissue factor-dependent and -independent pathways of systemic coagulation activation in acute myeloid leukemia: a single-center cohort study. Exp Hematol Oncol 2015;4:22

86 Jahr S, Hentze H, Englisch S, et al. DNA fragments in the blood plasma of cancer patients: quantitations and evidence for their origin from apoptotic and necrotic cells. Cancer Res 2001;61(04): 1659-1665

87 Gould TJ, Lysov Z, Liaw PC. Extracellular DNA and histones: double-edged swords in immunothrombosis. J Thromb Haemost 2015;13(Suppl 1):S82-S91

88 Kwee S, Song MA, Cheng I, Loo L, Tiirikainen M. Measurement of circulating cell-free DNA in relation to $18 \mathrm{~F}$-fluorocholine PET/CT imaging in chemotherapy-treated advanced prostate cancer. Clin Transl Sci 2012;5(01):65-70

89 Lysov Z, Dwivedi DJ, Gould TJ, Liaw PC. Procoagulant effects of lung cancer chemotherapy: impact on microparticles and cellfree DNA. Blood Coagul Fibrinolysis 2017;28(01):72-82

90 Oehmcke S, Mörgelin M, Herwald H. Activation of the human contact system on neutrophil extracellular traps.J Innate Immun 2009; 1(03):225-230

91 Ivanov I, Shakhawat R, Sun MF, et al. Nucleic acids as cofactors for factor XI and prekallikrein activation: different roles for high-molecular-weight kininogen. Thromb Haemost 2017;117(04):671-681

92 Noubouossie DF, Whelihan MF, Yu YB, et al. In vitro activation of coagulation by human neutrophil DNA and histone proteins but not neutrophil extracellular traps. Blood 2017;129(08):1021-1029

93 Kannemeier C, Shibamiya A, Nakazawa F, et al. Extracellular RNA constitutes a natural procoagulant cofactor in blood coagulation. Proc Natl Acad Sci U S A 2007;104(15):6388-6393

$94 \mathrm{Vu}$ TT, Leslie BA, Stafford AR, Zhou J, Fredenburgh JC, Weitz JI. Histidine-rich glycoprotein binds DNA and RNA and attenuates their capacity to activate the intrinsic coagulation pathway. Thromb Haemost 2016;115(01):89-98

95 Swystun LL, Mukherjee S, Liaw PC. Breast cancer chemotherapy induces the release of cell-free DNA, a novel procoagulant stimulus. J Thromb Haemost 2011;9(11):2313-2321

96 Fuchs TA, Brill A, Duerschmied D, et al. Extracellular DNA traps promote thrombosis. Proc Natl Acad Sci U S A 2010;107(36): 15880-15885
97 Semeraro F, Ammollo CT, Morrissey JH, et al. Extracellular histones promote thrombin generation through platelet-dependent mechanisms: involvement of platelet TLR2 and TLR4. Blood 2011;118(07):1952-1961

98 Semeraro F, Ammollo CT, Esmon NL, Esmon CT. Histones induce phosphatidylserine exposure and a procoagulant phenotype in human red blood cells. J Thromb Haemost 2014;12(10): 1697-1702

99 Ammollo CT, Semeraro F, Xu J, Esmon NL, Esmon CT. Extracellular histones increase plasma thrombin generation by impairing thrombomodulin-dependent protein $\mathrm{C}$ activation. J Thromb Haemost 2011;9(09):1795-1803

100 Coffelt SB, Wellenstein MD, de Visser KE. Neutrophils in cancer: neutral no more. Nat Rev Cancer 2016;16(07):431-446

101 Demers M, Wagner DD. NETosis: a new factor in tumor progression and cancer-associated thrombosis. Semin Thromb Hemost 2014;40(03):277-283

102 Thålin C, Demers M, Blomgren B, et al. NETosis promotes cancerassociated arterial microthrombosis presenting as ischemic stroke with troponin elevation. Thromb Res 2016;139:56-64

103 Brill A, Fuchs TA, Savchenko AS, et al. Neutrophil extracellular traps promote deep vein thrombosis in mice. J Thromb Haemost 2012;10(01):136-144

104 McDonald B, Davis RP, Kim SJ, et al. Platelets and neutrophil extracellular traps collaborate to promote intravascular coagulation during sepsis in mice. Blood 2017;129(10):1357-1367

105 Massberg S, Grahl L, von Bruehl ML, et al. Reciprocal coupling of coagulation and innate immunity via neutrophil serine proteases. Nat Med 2010;16(08):887-896

106 von Brühl ML, Stark K, Steinhart A, et al. Monocytes, neutrophils, and platelets cooperate to initiate and propagate venous thrombosis in mice in vivo. J Exp Med 2012;209(04):819-835

107 Gould TJ, Vu TT, Swystun LL, et al. Neutrophil extracellular traps promote thrombin generation through platelet-dependent and platelet-independent mechanisms. Arterioscler Thromb Vasc Biol 2014;34(09):1977-1984

108 Meikle CK, Kelly CA, Garg P, Wuescher LM, Ali RA, Worth RG. Cancer and thrombosis: the platelet perspective. Front Cell Dev Biol 2017;4:147

109 Walsh PN, Griffin JH. Platelet-coagulant protein interactions in contact activation. Ann N Y Acad Sci 1981;370:241-252

110 Müller F, Mutch NJ, Schenk WA, et al. Platelet polyphosphates are proinflammatory and procoagulant mediators in vivo. Cell 2009; 139(06):1143-1156

111 Riedl J, Preusser M, Nazari PM, et al. Podoplanin expression in primary brain tumors induces platelet aggregation and increases risk of venous thromboembolism. Blood 2017;129(13):1831-1839

112 Suzuki-Inoue K, Kato Y, Inoue O, et al. Involvement of the snake toxin receptor CLEC-2, in podoplanin-mediated platelet activation, by cancer cells. J Biol Chem 2007;282(36):25993-26001

113 Kuter DJ. Thrombotic complications of central venous catheters in cancer patients. Oncologist 2004;9(02):207-216

114 Verso M, Agnelli G. Venous thromboembolism associated with long-term use of central venous catheters in cancer patients. J Clin Oncol 2003;21(19):3665-3675

115 Rajasekhar A, Streiff MB. How I treat central venous access device-related upper extremity deep vein thrombosis. Blood 2017;129(20):2727-2736

116 Jaffer IH, Fredenburgh JC, Hirsh J, Weitz JI. Medical deviceinduced thrombosis: what causes it and how can we prevent it? J Thromb Haemost 2015;13(Suppl 1):S72-S81

117 Gorbet MB, Sefton MV. Biomaterial-associated thrombosis: roles of coagulation factors, complement, platelets and leukocytes. Biomaterials 2004;25(26):5681-5703

118 Yau JW, Stafford AR, Liao P, Fredenburgh JC, Roberts R, Weitz JI. Mechanism of catheter thrombosis: comparison of the antithrombotic activities of fondaparinux, enoxaparin, and heparin in vitro and in vivo. Blood 2011;118(25):6667-6674 
119 Yau JW, Stafford AR, Liao P, et al. Corn trypsin inhibitor coating attenuates the prothrombotic properties of catheters in vitro and in vivo. Acta Biomater 2012;8(11):4092-4100

120 Yau JW, Liao P, Fredenburgh JC, et al. Selective depletion of factor XI or factor XII with antisense oligonucleotides attenuates catheter thrombosis in rabbits. Blood 2014;123(13):2102-2107

121 Farge D, Bounameaux H, Brenner B, et al. International clinical practice guidelines including guidance for direct oral anticoagulants in the treatment and prophylaxis of venous thromboembolism in patients with cancer. Lancet Oncol 2016;17(10):e452-e466

122 Alibeik S, Zhu S, Yau JW, Weitz JI, Brash JL. Surface modification with polyethylene glycol-corn trypsin inhibitor conjugate to inhibit the contact factor pathway on blood-contacting surfaces. Acta Biomater 2011;7(12):4177-4186

123 Eikelboom JW, Connolly SJ, Brueckmann M, et al; RE-ALIGN Investigators. Dabigatran versus warfarin in patients with mechanical heart valves. N Engl J Med 2013;369(13):1206-1214

124 Renné T, Pozgajová M, Grüner S, et al. Defective thrombus formation in mice lacking coagulation factor XII. J Exp Med 2005;202(02):271-281

125 Nickel KF, Long AT, Fuchs TA, Butler LM, Renné T. Factor XII as a therapeutic target in Thromboembolic and inflammatory diseases. Arterioscler Thromb Vasc Biol 2017;37(01):13-20

126 Fredenburgh JC, Gross PL, Weitz JI. Emerging anticoagulant strategies. Blood 2017;129(02):147-154

127 Hansson KM, Nielsen S, Elg M, Deinum J. The effect of corn trypsin inhibitor and inhibiting antibodies for FXIa and FXIIa on coagulation of plasma and whole blood. J Thromb Haemost 2014;12(10):1678-1686

128 May F, Krupka J, Fries M, et al. FXIIa inhibitor rHA-Infestin-4: Safe thromboprotection in experimental venous, arterial and foreign surface-induced thrombosis. Br J Haematol 2016;173(05):769778

129 Xu Y, Cai TQ, Castriota G, et al. Factor XIla inhibition by Infestin4: in vitro mode of action and in vivo antithrombotic benefit. Thromb Haemost 2014;111(04):694-704

130 Kleinschnitz C, Stoll G, Bendszus M, et al. Targeting coagulation factor XII provides protection from pathological thrombosis in cerebral ischemia without interfering with hemostasis. J Exp Med 2006;203(03):513-518

131 Matafonov A, Leung PY, Gailani AE, et al. Factor XII inhibition reduces thrombus formation in a primate thrombosis model. Blood 2014;123(11):1739-1746

132 Larsson M, Rayzman V, Nolte MW, et al. A factor XIla inhibitory antibody provides thromboprotection in extracorporeal circulation without increasing bleeding risk. Sci Transl Med 2014;6 (222):222ra17

133 Björkqvist J, de Maat S, Lewandrowski U, et al. Defective glycosylation of coagulation factor XII underlies hereditary angioedema type III. J Clin Invest 2015;125(08):3132-3146

134 Weitz JI, Fredenburgh JC. Factors XI and XII as targets for new anticoagulants. Front Med (Lausanne) 2017;4:19
135 Wu W, Li H, Navaneetham D, Reichenbach ZW, Tuma RF, Walsh PN. The kunitz protease inhibitor domain of protease nexin-2 inhibits factor XIa and murine carotid artery and middle cerebral artery thrombosis. Blood 2012;120(03):671-677

136 Ma D, Mizurini DM, Assumpção TC, et al. Desmolaris, a novel factor XIa anticoagulant from the salivary gland of the vampire bat (Desmodus rotundus) inhibits inflammation and thrombosis in vivo. Blood 2013;122(25):4094-4106

137 Wong PC, Crain EJ, Watson CA, Schumacher WA. A smallmolecule factor XIa inhibitor produces antithrombotic efficacy with minimal bleeding time prolongation in rabbits. J Thromb Thrombolysis 2011;32(02):129-137

138 Quan ML, Wong PC, Wang C, et al. Tetrahydroquinoline derivatives as potent and selective factor XIa inhibitors. J Med Chem 2014;57(03):955-969

139 Hangeland JJ, Friends TJ, Rossi KA, et al. Phenylimidazoles as potent and selective inhibitors of coagulation factor XIa with in vivo antithrombotic activity. J Med Chem 2014;57(23):9915-9932

140 Tucker EI, Marzec UM, White TC, et al. Prevention of vascular graft occlusion and thrombus-associated thrombin generation by inhibition of factor XI. Blood 2009;113(04):936944

141 Tucker EI, Verbout NG, Leung PY, et al. Inhibition of factor XI activation attenuates inflammation and coagulopathy while improving the survival of mouse polymicrobial sepsis. Blood 2012;119(20):4762-4768

142 Cheng Q, Tucker EI, Pine MS, et al. A role for factor XIIa-mediated factor XI activation in thrombus formation in vivo. Blood 2010; 116(19):3981-3989

143 Büller HR, Bethune C, Bhanot S, et al; FXI-ASO TKA Investigators. Factor XI antisense oligonucleotide for prevention of venous thrombosis. N Engl J Med 2015;372(03):232-240

144 Gailani D, Bane CE, Gruber A. Factor XI and contact activation as targets for antithrombotic therapy. J Thromb Haemost 2015;13 (08):1383-1395

145 Woodruff RS, Xu Y, Layzer J, Wu W, Ogletree ML, Sullenger BA. Inhibiting the intrinsic pathway of coagulation with a factor XIItargeting RNA aptamer. J Thromb Haemost 2013;11(07): 1364-1373

146 Travers RJ, Shenoi RA, Kalathottukaren MT, Kizhakkedathu JN, Morrissey JH. Nontoxic polyphosphate inhibitors reduce thrombosis while sparing hemostasis. Blood 2014;124(22): 3183-3190

147 Bollen L, Peetermans M, Peeters M, et al. Active PAI-1 as marker for venous thromboembolism: case-control study using a comprehensive panel of PAI-1 and TAFI assays. Thromb Res 2014;134 (05):1097-1102

148 Fuchs HJ, Borowitz DS, Christiansen DH, et al; The Pulmozyme Study Group. Effect of aerosolized recombinant human DNase on exacerbations of respiratory symptoms and on pulmonary function in patients with cystic fibrosis. N Engl J Med 1994;331(10): 637-642 